ISSN (e)-2347-176x ISSN (p) 2455-0450

crossrefDOI: https://dx.doi.org/10.18535/jmscr/v7i1.88

\title{
Role of Antinuclear Antibody in Diagnosing Connective Tissue Disease: A Retrospective Study of 5 Year Duration
}

\author{
Authors \\ Dr Sachin Sharma ${ }^{1}$, Dr C.V. Kulkarni ${ }^{2}$, Dr A. Panchonia ${ }^{3}$, Dr Vipin Todase \\ ${ }^{1}$ Assistant Prof, Dept of Pathology, M.G.M Medical College, Indore, M.P state, India \\ ${ }^{2}$ Prof \&Head. Pathology, M.G.M Medical College, Indore, M.P state, India \\ ${ }^{3}$ Professor Pathology, M.G.M Medical College, Indore, M.P state, India \\ *Corresponding Author \\ Dr Vipin Todase \\ Email: vips.todase@gmail.com
}

\begin{abstract}
Antinuclear antibody is being used for the diagnosis of connective tissue disorders from many years. This article gives an antinuclear antibody detection methods and use of these tests for diagnosis of connective tissue disorder. For the detection of ANA immunoflorescence technology is used. The Aims and objective of the study is to find out the role of antinuclear antibody in diagnosing connective tissue disease and to find out the prevalence of positive cases Retrospective study was carried out in department of pathology M.G.M. Medical college and M.Y. Hospital Indore during 5 year duration. The cases with Antinuclear antibody investigation were taken from the records. Positive cases were separated out and then correlation with the presence of connective tissue disease or not is made. 200 cases for ANA investigation were studied and we found that 20 cases are positive while 110 cases are equivocal whereas 70 were negative. Equivocal cases were investigated again after one weak than 15 cases become positive. Follow up was carried out for positive cases and we found that 8 cases have different connective tissue disorders. From this study we make out that the chances of connective tissue disorders are more with the positive ANA cases and we must go through the screening procedure.
\end{abstract}

Keywords: antinuclear antibody ANA, connective tissue disorders.

\section{Introduction}

Connective tissue diseases (CTD) are a group of autoimmune disorders which are characterized by presence of antinuclear antibodies (ANA) in the blood of patients. ANA are autoantibodies that have the ability of binding and destroying certain structures within the nucleus of the cells ${ }^{[1]}$. ANA antibodies involved in the pathogenesis of disease and basis for CTD workup. Antinuclear antibodies are also known as antinuclear factor or $\mathrm{ANF}^{[2]}$ are autoantibodies which binds to cell nucleus and its contents. In contrast to normal individuan some individuals produce antibodies to human antigens. serum autoantibodies are detected present in an individual's blood. The common tests used for detecting and quantifying ANAs are indirect immunofluorescence and enzyme-linked immunosorbent assay (ELISA). The level of autoantibodies titre is calculated and reported. 
ANAs are related to diseases like systemic lupus erythematosus (SLE), rheumatoid arthritis, scleroderma, Sjögren's syndrome, polymyositis, primary biliary cirrhosis, dermatomyositis, drug induced lupus, autoimmune hepatitis, multiple sclerosis, thyroid disease, antiphospholipid syndrome, discoid lupus,juvenile idiopathic arthritis, psoriatic arthritis, juvenile dermatomyositis, idiopathic thrombocytopaenic purpura, some infection even in some cancer and normal individuals. These antibodies can be further classified as per there specificity, and each subset has different propensities for specific disorders. ${ }^{[3][4]}$

\section{Materials and Methods}

A retrospective study was carried out in the department of pathology M.G.M. medical college Indore. Records are studied. Total 200 cases are there registered for ANA testing. In the pathology department it was carried out by enzyme-linked immunosorbent assay (ELISA). Indirect immunofluorescence is one of the most commonly used. To tests for ANAs, HEp-2 cells are used as a substrate and antibodies ae detected in serum in human serum.

The test is considered positive if titre of $1: 40 / 1: 80$ is observed. Higher titres are more clinically significant. Low positives $(\leq 1: 160)$ can be seen in up to $20 \%$ of healthy individuals, especially the elderly. 5\% of the healthy population can have ANA titres of 1:160 or higher.

\section{Results}

The cases with Antinuclear antibody investigation were searched from records. Positive cases were correlated with the presence of connective tissue disease. 200 cases for ANA investigation were studied and we found that 20 cases are positive while 110 cases are equivocal whereas 70 were negative. Follow up was carried out for positive cases and we found that 8 cases have different connective tissue disorders. Equivocal cases were investigated again after one weak than 15 cases become positive.
Table 1 Distribution of cases

\begin{tabular}{|l|c|c|}
\hline Test & No. of cases & $\%$ \\
\hline Positive & 20 & $10 \%$ \\
\hline Negative & 70 & $35 \%$ \\
\hline Equivocal & 110 & $55 \%$ \\
\hline Total & 200 & \\
\hline
\end{tabular}

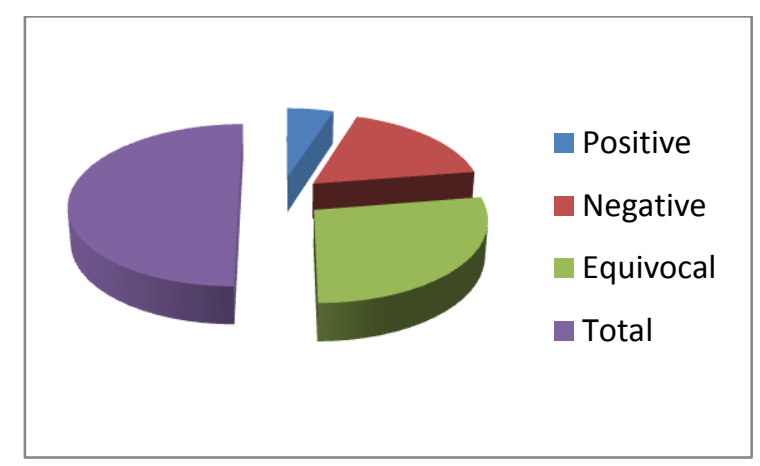

Table 2 Sex wise distribution

\begin{tabular}{|l|c|c|}
\hline Sex & No of cases & $\%$ \\
\hline Male & 60 & $30 \%$ \\
\hline Female & 140 & $70 \%$ \\
\hline Total & 200 & \\
\hline
\end{tabular}

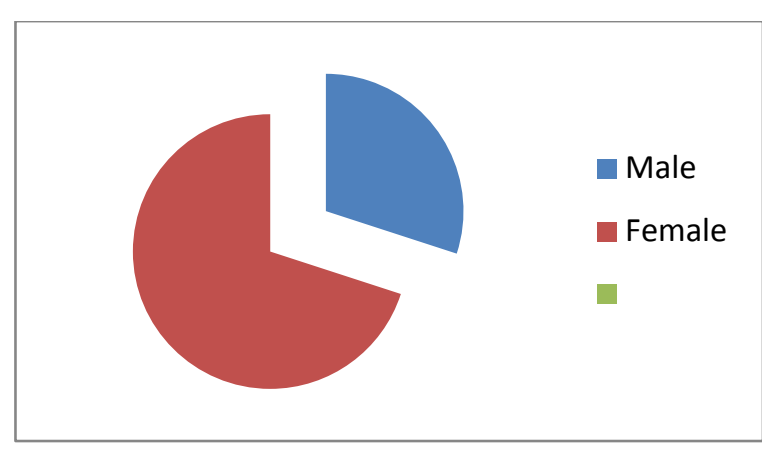

Table 3 Distribution of cases with connective tissue disorders

\begin{tabular}{|l|c|}
\hline Cases & Connective tissue disorders \\
\hline 5 & Rheumatic disease \\
\hline 2 & SLE \\
\hline 1 & Sjogren syndrome \\
\hline
\end{tabular}

Table 4 Distribution of cases with age groups

\begin{tabular}{|c|c|c|}
\hline Age group & Cases & $\%$ \\
\hline $0-$ 20 year & 60 & $30 \%$ \\
\hline $21-40$ year & 20 & $10 \%$ \\
\hline $41-60$ year & 120 & $60 \%$ \\
\hline
\end{tabular}

\section{Discussion}

The presence of ANA is a hallmark of rheumatic or autoimmune disease. dsDNA antibodies and antibodies against other nuclear antigens gives positive ANA-IIF. 
In the female group, two peaks in ANA positivity at the 20-year and 40-year age are observed. ANA prevalence correlation with age is positive correlation. Higher prevalence is observed in the 20to 30 -year and 40- to 50-year age groups which is nearly similar to our study. ${ }^{[5]}$ Dipti R, et al show in their study that ANA positivity in boys $(3.7 \%)$ is lower than in girls $(9.2 \%)$, showing that females have a higher ANA titer than males. Similar results are observed in our study. Malleson, et al found in their study that raised titers of ANA are useful in the diagnosis of rheumatic diseases. It is important as low titer is less significant than a high titer and it can be seen even in normal individuals. Studies aer being carried to determine the screening dilution of sera for ANA testing. A titer of 1:160 is considered for the diagnosis of CTDs in majority of laboratories $^{[8,9]}$.

A positive ANA test should be correlated with clinical evaluation and in the absence of signs and, test only confounds the diagnosis. A positive ANA test can also be seen in healthy individuals, particularly the elderly or in a wide range of diseases other than CTD, where it has no diagnostic or prognostic value.

Every CTD has its specific antibody at times it is difficult to specify $\mathrm{it}^{[10,11]}$. The test therefore is mainly used for screening rather than to diagnose a CTD. A study by Verstegen et al, ${ }^{[12]}$ observed $42.6 \%$ of 6422 consecutively tested patients at a large community hospital were ANA-positive (1:80), and Marin et $\mathrm{al}^{[13]}$ studies the prevalence of ANA positivity (1:40) in a group of 304 healthy individuals to be $54.3 \%$.

\section{Conclusion}

In our study we concluded that ANA is crucial to screen and diagnose autoimmune disorders, when correlated clinically it can be use as a diagnostic tool. The proper laboratory tests use in accordance to knowledge and communication between pathologist and clinician can significantly improves the diagnostic yield of specialized tests. From this study we make out that the chances of connective tissue disorders are more with the positive ANA cases and we must go through the screening procedure.

\section{Acknowledgement}

Authors acknowledge the immense help received from Dept. of Pathology of M.G.M Medical College, Indore., the scholars whose articles are cited and included in references of this manuscript. the authors are also grateful to authors/ editors/ publishers of all those articles, journals and books from where the literature for this article has been reviewed and discussed. Our colleagues who supported us.

\section{References}

1. Walravens M: Systemic diseases and the detection of nuclear and anticytoplasmic antibodies. A historical review. Clin Rheumatol 1987, 6:9-17

2. Jump up $\wedge$ "Medical Subject Headings (MeSH)". National Library of Medicine. Retrieved 12 February 2013

3. Kavanaugh A, Tomar R, Reveille J, Solomon DH, Homburger HA (January 2000). "Guidelines for clinical use of the antinuclear antibody test and tests for specific autoantibodies to nuclear antigens. American College of Pathologists". Archives of pathology \& laboratory medicine. 124 (1): 71-81.doi: $\quad 10.1043 / 00039985$

(2000) 124<0071:GFCUOT>2.0.CO;2 (inactive 2017-01-15). PMID 10629135

4. Malleson PN, Mackinnon MJ, Sailer-Hoeck M, Spencer CH (2010). "Review for the generalist: The antinuclear antibody test in children - When to use it and what to do with a positive titer". Pediatr Rheumatol Online J. 8: 27. doi:10.1186/1546-0096-8-27. PMC 2987328 ə. PMID 20961429.

5. M, Chan EK, HoLA, etal. Prevalence and socio demographic correlates of antinuclear antibodies in the United States. Arthritis Rheum. 2012;64: 2319-2327

6. Dipti TR, Azam MS, Sattar MH, etal. Detection of anti-nuclear anti body by 
immunofluorescence assay and enzyme immunoassay in childhood systemic lupus erythematosus: experience from Bangladesh. Int J Rheum Dis. 2012;15:121-125.

7. Malleson, Sailer, Mackinnon. Usefulness of antinuclear antibody testing to screen forrheumaticdiseases.Arch.Dis.Child1997;7 7(4):299-304

8. Ghosh P, Dwivedi S, Naik S, Agarwal V, Verma A, Aggarwal A, Misra R. Antinuclear antibodies by indirect immunofluorescence: Optimum screening dilution for diagnosis of systemic lupus erythematosus. Indian J Med Res. 2007;126:34-38. [PubMed]

9. Kiuttu J, Hartikainen A, Makitalo R. Occurrence of antinuclear antibodies in an unselected pregnancy population. Gynecol Obstet Invest. 1994;37:160-163. [PubMed]

10. Feltkamp TE. Antinuclear antibody determination in a routine laboratory. Ann Rheum Dis. 1996;55:723-727. doi: 10.1136/ard.55.10.723. [PMC free article] [PubMed] [Cross Ref]

11. Greidinger E, Hoffman R. Antinuclear Antibody Testing: Methods, Indications, and Interpretation, $\mathrm{CE}$ Update Course in Laboratory Medicine. 2003. pp. 113-118.

12. Verstegen G, Duyck MC, Meeus P, et al. Detection and identification of antinuclear antibodies (ANA) in a large community hospital. Acta Clin Belg. 2009;64:317-323.

13. Marin GG, Cardiel MH, Cornejo H, Viveros ME. Prevalence of antinuclear antibodies in 3 groups of healthy individuals: blood donors, hospital personnel, and relatives of patients with autoimmune diseases. J Clin Rheumatol. 2009;15:325-329 